\title{
E-Consumer Behavior: The Roles of Attitudes, Risk Perception on Shopping Intention-Behavior
}

\author{
Widayat \\ University of Muhammadiyah Malang, Malang, East Java, Indonesia \\ (e-mail) widayat@umm.ac.id
}

\begin{abstract}
The objective of this research is to examine the roles of attitudes, the risk perception of intention and behavior online shopping, among students. The data were collected from the samples through a five-Likert scale questionnaire. The samples of adolescents who were still studying in Malang city were 500 persons, that taken using an accidental sampling technique. The data for building the purposed model was verified in terms of the completeness, the existence of outliers and the normal distribution. The Structure Equation Model was build supported by AMOS version 18. From the adequate data, a good structural model was built with the Goodness of Fit values: RMSEA=0,079; AGFI=0,857; GFI=0,891; CFI=0,910; TLI=0,892. The result showed that the attitudes towards online shops played positive and significant roles in promoting the online shopping intention and also risk perception but in a negative direction. The other finding was that online shopping behavior made by the adolescents was not based on their intention. The implication for improving the intention and behavior on the online store can be improved by building an interesting attitude of online stores attributes and minimize the consumer's risks, such as the accuracy of time order delivery, the consumer private data protection.
\end{abstract}

Keywords: online shopping, behavior, intention, attitude, Risk Perception, Consumer

\section{Introduction}

A technology of information and communication has been growing at an incredible speed. One of the signs of the development is the wider use of the Internet in daily life (Garg, 2016; Masoud, 2013). The Internet has been penetrating into and playing important roles in the life of human beings all over the world (Katawetawaraks \& Wang, 2011), including in the field of business. This condition gives impacts on the internet-based businesses with various forms and names such as e-shop, e-store, Internet shop, web-shop, web-store, online store, and virtual shop that have been growing well (Arshad, Zafar, Fatima, \& Khan, 2015a; Bhatt1, 2014; Shergill \& Chen, 2005; Suresh \& Shashikala, 2011; Vaghela, 2014; Zhou, Dai, \& Zhang, 2007), and happens in various parts in the world, including Indonesia. The existence of the Internet-based shopping or usually called online shopping causes Indonesian people to be faced with two choices of shopping: off-line in shops or other types of shops that are physically established in a certain place or online shopping, or a virtual shopping place which is physically inexistent in a certain place. Each has its own strengths and weaknesses. Various benefits from online shopping are as follows: the ease of shopping, time efficiency, time flexibility, shopping that may be made in remote areas, improving the consumers' intent to buy, trials through online shopping, and the like. Clearly, online shops are preferred or tend to be preferred and popular among modern people (Bashar \& Wasiq, 2013; Chandra \& Sinha, 2013; Haryo \& Budhi, 2015; Jun \& Jaafar, 2011).

The number of online shoppers, in general, has been significantly growing all over the world (Akin \& Seçilmişb, 2015; Cheng, Liu, \& Wu, 2013). The results of a survey made by The Nielsen Global Survey of E-Commerce on consumers possessing internet access in 60 countries ((Nielsen, 2014), 
showed that online shopping of daily needs such as the airplane tickets, fashions, hotels, and travel, has been increasing in number. In Indonesia, since 2010, in line with the significant increase and changes of the provision of products and services from the online-based retailers, online shopping has been increasing and popular. Consumers at present tend to use online media and look for online paths to examine or look for products or services needed and wanted. Meanwhile, the results of the survey made by Indonesian Internet Service Provider Association (APJII) stated that the penetration level of Internet users in Indonesia in 2012 was 24.23\%, but in 2014 its growth reached 34.9\% (APJII, 2014). Some of the internet users were for business transactions or shopping so that the penetration of the internet also gave effects on the use of online shopping. What is interesting viewed from the demographic aspect is that the use of the internet for shopping is mostly dominated by the age group of fewer than 40 years. The increasing number of online shoppers is triggered by the growing number of various kinds of online shops. Moreover, the stimulus was given by the sellers or online shops, interesting visualizations, service quality (Ahmad, Vanja, \& Wamadeva, 2014), the ease of shopping (Hsu \& Bayarsaikhan, 2012b), and also infrastructures also support the growing online shopping. The question is: what is the basis of the consumers to intend to do online shopping.

The changes of the consumers from offline shopping into online one is interesting to study (Hsu \& Bayarsaikhan, 2012b), not only in terms of the empirical phenomenon side but also from the theoretical side. It is the empirical model which has been being developed up to now. In the academic perspective, the shift has practical, empirical and theoretical consequences. At the theoretical level, there will be some changes in variables or factors that may explain why it occurs. Moreover, it is necessary to redesign or restudy the theories that have been used to explain the phenomenon that has been changed and also it is important to introduce a more appropriate theory. Studies trying to apply basic theories on online shopping behavior that haven much been found, but the results varied among one research and another. One of the models well-known in various pieces of literature is a cognitive behavioral model.

Studies trying to apply the basic theories on online shopping behavior have been made, but the results varied between one types of research and another. One of the models well known in various literatures is Cognitive Behavioral Model. The models used in explaining a shopping phenomenon are among others Theory of Planned Behavior (TPB), and Theory of Reason Action (TRA) (Ajzen, 1991, 2011). TPB model is generally used to explain the phenomenon of the use of ICT in shopping. Some researchers have tried to apply the TPB to explain the shopping behavior on the Internet, for examples George (2004) and Johar and Awalluddin (2011), Yulihasri, Islam, and Daud (2011), and Jin, Abdullah, Nizam, Rahim, and Safizal (2016). Dissimilarity or even inconsistency of the findings has motivated researchers to fill in the gap.

Empirically, dealing with various evidences on the explanatory variables of the online shopping intention and behavior, Adnan (2014) made a research intended to test the determinant of online shopping in Pakistan. From his research, it was found that consumer hedonic motivation and the website condition influenced shopping attitude and behavior. Another factor tested was the risk perception, and the result showed that the variable gave some effects but negative ones. In line with the research, Ganapathi (2015) tried to test the factors influencing online shopping behavior in Chennai. Using a regression analysis, it was known that security significantly positive influence on the consumers' online shopping behavior.

In general, actually, some people still hesitate to do online shopping. There is a research showing that online shopping makes some people frustrated and upset with this kind of shopping. They even were worried that this shopping would bother their privacy, as a result, they were reluctant to buy something through the online shop (Dai, Forsythe, \& Kwon, 2014), including consumers in Indonesia. Their hesitation was especially caused by the fact that they did not directly meet or interact with the sellers. This shows that security is one of the important factors that may influence the decision to do online shopping. Evidence from another research showed that consumers' perception of risk or an online shopping system determined shopping intention and behavior. Some related researchers 
showed that the security factor (Yulihasri et al., 2011), consumers or candidate consumers' attitudes towards online shopping system (Ariff, Sylvester, Zakuan, Ismail, \& Ali, 2014), and risk perception (Dai et al., 2014; Hong, Zulkiffli, \& Hamsani, 2016; Hsu \& Bayarsaikhan, 2012a; Maziriri \& Chuchu, 2017), are factors contributing to the online shopping intention.

Evaluation of either the goodness and the badness of online shops that may cause the feelings of like or dislike and the perception built by the consumers on the weaknesses they would suffer from has given various empirical evidence between one researcher and another. Therefore, this theme is still appropriate to study. From the description about this phenomenon, and the empirical evidence above, the phenomenon of the consumers', especially adolescents' behavior to online shopping needs to be studied. Based on the description above, the hypotheses are:

$\mathrm{H}_{1}$ Shopping intention plays significant roles in online shopping behavior

$\mathrm{H}_{2}$ Attitude towards online shops plays significantly positive roles in online shopping intention

$\mathrm{H}_{3}$ Risk perception plays significantly negative roles in the interest in online shopping

\section{Methods}

The objective of this present research is to test the roles of the attitude and risk perception variables in online intention and behavior. The testing was made by positioning variables of attitudes toward online shop and risk perception to unobservable variables namely online shopping intention and attitude. The objective of this present research would be reached by applying a quantitative causality approach.

The research population is the whole universe, as the field of generalization in this present research was adolescents at the age from 13 to 25 years, with accesses to the internet either the mobile phone, Smartphone or other media. The adolescents were university students staying or studying in Malang city, East Java, Indonesia. Five hundred adolescents were sampled as respondents using accidental sampling technique. They were intentionally meet by the enumerators of this research in their campuses.

Variables that would be used to build the model in this research were latent variables which were measured using items of measuring indicators, and which are presented in detail in Table 1.

Table 1 Variable and its measuring Indicator

\begin{tabular}{|c|c|c|}
\hline Variable & $\begin{array}{l}\text { Operational } \\
\text { Definition }\end{array}$ & Measurement Item (Code of item) \\
\hline $\begin{array}{l}\text { Attitude } \\
\text { toward } \\
\text { shop }\end{array}$ & $\begin{array}{l}\text { Positive or negative } \\
\text { feeling of online shops } \\
\text { (Ahmad et al., 2014; } \\
\text { Bhatt1, 2014; Dijst, Farag, } \\
\text { \& Schwanen, 2005; Li \& } \\
\text { Zhang, 2002; Teo, 2010) }\end{array}$ & $\begin{array}{l}\text { - Goods ordered arrived on time Att1) } \\
\text { - The information is provided completely in details } \\
\text { (Att2) } \\
\text { - The goods may be bought anytime for } 24 \text { hours } \\
\text { (Att3) } \\
\text { - The online shopping may choose and compare } \\
\text { goods easily (Att4) } \\
\text { - The online shop feature may help look for } \\
\text { information about products that will be bought } \\
\text { (Att5) } \\
\text { - The design and the layout of the online shop help } \\
\text { facilitate to look for the products that will be } \\
\text { bought (Att6) } \\
\text { - Online shopping may save time (Att7) } \\
\text { - Online shopping does not waste time (Att8) } \\
\text { - Online shopping is not boring (Att9) }\end{array}$ \\
\hline Risk perception & $\begin{array}{l}\text { Evaluation of anything } \\
\text { resulting some loses to } \\
\text { have when one does } \\
\text { online shopping (Akin \& }\end{array}$ & $\begin{array}{l}\text { - The quality of the goods bought is not in line with } \\
\text { the offered guarantee (Risk1) } \\
\text { - It might possible the online shops cheat (Risk1) } \\
\text { - The ordered goods arrive on time as informed by }\end{array}$ \\
\hline
\end{tabular}




\begin{tabular}{|c|c|c|}
\hline & $\begin{array}{l}\text { Seçilmişb, 2015; Ariff et } \\
\text { al., 2014; Cheng, Liu, \& } \\
\text { Wu, 2013; Hong, Zulkiffli, } \\
\text { \& Hamsani, 2016; } \\
\text { Mariani, 2012; Masoud, } \\
\text { 2013; Shafeeque \& } \\
\text { Thomachan, 2017; Sreya \& } \\
\text { Raveendran, 2016) }\end{array}$ & $\begin{array}{l}\text { the online shop (Risk1) } \\
\text { - The goods ordered might not be conveyed to the } \\
\text { buyer (Risk1) } \\
\text { - There is feeling that personal data will be misused } \\
\text { by the third party or other people (Risk1) } \\
\text { - It might get the default or unusable goods (Risk1) } \\
\text { - It might get expired goods } \\
\text { - It is not easy to cancel the transaction in buying } \\
\text { goods in online shops (Risk1) } \\
\text { - The goods ordered might be default due to the } \\
\text { packaging agency (Risk1) } \\
\text { - Online shops are used for shopping (Risk1) }\end{array}$ \\
\hline $\begin{array}{l}\text { Shopping on E- } \\
\text { shop Intention }\end{array}$ & $\begin{array}{l}\text { The interest to shop in the } \\
\text { future through online } \\
\text { shops (Galina, Oleksiy, \& } \\
\text { Karina, 2016; Haryo \& } \\
\text { Budhi, 2015; Hsu \& } \\
\text { Bayarsaikhan, 2012; } \\
\text { Kautonen, Van Gelderen, } \\
\text { \& Fink, 2015) }\end{array}$ & $\begin{array}{l}\text { - There is the intention to continue using online } \\
\text { shops (IntenOL1) } \\
\text { - Online shopping is done when ordinary shops do } \\
\text { not provide the needed goods (IntenOL2) }\end{array}$ \\
\hline $\begin{array}{l}\text { E-shopping } \\
\text { behavior }\end{array}$ & $\begin{array}{l}\text { Action Shopping using } \\
\text { online shops(Arshad, } \\
\text { Zafar, Fatima, \& Khan, } \\
\text { 2015; Chandra \& Sinha, } \\
\text { 2013; Jain, Goswami, \& } \\
\text { Bhutani, 2014; Shirokova, } \\
\text { Osiyevskyy, \& } \\
\text { Bogatyreva, 2016; Smith et } \\
\text { al., 2007) }\end{array}$ & $\begin{array}{l}\text { - The average frequency of shopping is shown in a } \\
\text { certain period (Behav02) } \\
\text { - No doubt is made in using online shops, beside } \\
\text { off-line shops (Behav03) }\end{array}$ \\
\hline
\end{tabular}

The data were collected from the sample respondents using written questionnaires with five-Likert Scale. The questionnaires tested in terms of their validity and reliability. The number of valid items in the questionnaires to measure the attitude toward e-shop is 9; risk perception is 8; shopping E-shop intention is 2; and online shopping behavior is 2 . Each item of the construct measuring variable has the validity value of more than 0.40 and each variable has the reliability value of the Alpha-Cronbach that is higher than 0.60. Items which were not valid and not reliable were deleted in this research.

The objective of this present research is to build a causality model consisting of a structural and measurement model. The model that relates to unobservable variables proposed in this present research was based on the data that fulfilled certain criteria. The data were obtained from the respondents via questionnaires. The questionnaires collected from the sample respondents were verified before being analyzed. The number of questionnaires distributed to the respondents was 500, but not all of the questionnaires fulfilled the requirements as the materials for building the model. There were merely 322 questionnaires that are appropriate for building the model. The final model that would be interpreted is the model fulfilling the requirements of Goodness of Fit (GOF), consisting of the following criteria: small or insignificant Likelihood ratio chi-square statistics, Probability higher than 0,05, Root Mean Square Error Approximation (RMSEA), Goodness of Fit Index (GFI), Adjusted Goodness of Fit Index (AGFI), CMIN/DF Tucker-Lewis Index (TLI), Comparative Fit Index (CFI). See Table 2. 
Table 2 Goodnes o Fit Index of the Model

\begin{tabular}{lc}
\hline \multicolumn{1}{c}{ Goodness of Fit Index } & Cut of Value \\
\hline$X^{2}$ Chi Square & Smaller than $X^{2}$ table \\
Significancy Probability & $\geq 0.05$ \\
RMSEA & $\leq 0.08$ \\
GFI & $\geq 0.90$ \\
AGFI & $\geq 0.90$ \\
CMIN/DF & $\leq 2.00$ \\
TLI & $\geq 0.95$ \\
CFI & $\geq 0.95$ \\
Source: Joseph F. Hair, William C. Black, Barry J.Babin, and Anderson (2009)
\end{tabular}

In the model that had fulfilled the GOF requirements, relationship paths existed between one latent variable and the other. The inter-variable relationship path was made to test the meaningfulness in line with the proposed hypothesis. The proposed hypothesis for each path was tested using a t-test for each causality relationship path. The testing was made by comparing the value of the T-count for each relationship path and that of the T-table with the significance level of $95 \%$ or alpha $5 \%$. If the value of the T-count is higher than that of the T-table, the working hypothesis (Ha) proposed is accepted, whereas the Null hypothesis (Ho) was not accepted

\section{Results and Discussion}

This present research used questionnaires as the tool to collect the data. From 500 questionnaires distributed to the sample respondents, an as a whole there were returned well and completely. However, before being used to build a model, the questionnaire-based data were needed to detect in terms of some matters as the requirements to build a model consisting of the outlier, distribution normality, and also the existence of missing data or invalid data. After the data requirements were identified, there were merely 322 data which were appropriate and could be used to build the model. The results of the modeling are presented in Figure 1.

Table 3 Goodness of fit of the full latest model

\begin{tabular}{lccc}
\hline GOF Measure & Cut-Off Value & Value of Modeling Result & Conclusion \\
\hline Chi-Square & Low & 234.177 & - \\
Probability & Higher & 0.000 & - \\
RMSEA & 0.080 & 0.079 & Good \\
AGFI & 0.900 & 0.857 & Good \\
GFI & 0.900 & 0.891 & Good \\
CFI & 0.900 & 0.910 & Good \\
TLI & 0.900 & 0892 & Good \\
\hline
\end{tabular}

Source : Amos Printout

In the model, it seems that the number of the attitude (online attitude) variables was 9 (nine) with each standardized coefficient value which was higher than that of the standardized value namely 0.70 . This indicates that the nine indicators are unidimensionally valid for measuring the construction of the attitude variable. At the risk perception variable, the early design of the number of the measuring indicator was ten. But, there were some indicators which were invalid with the standardized coefficient value which was lower than 0.5 . The indicators were Risk 4 and Risk5 so that they were not used as the indicators for measuring the perception variable of the risks in online shopping. Other indicators which were said to be valid with the standardized coefficient value ranged from 0.74 to 0.88. Meanwhile, the online transaction or shopping intention and the online shopping behavior were merely each measured using two indicators. The online shopping intention variable was measured by IntenOL1 and IntenOL2 with the standardized coefficient values of 0.69 and 0.83 respectively. Different from other variables, online shopping behavior was measured with Behav02 (0.65) and Behav03 (-0.65), each with the coefficient value which was relatively low or was lower than 0.70 , but 
both were still appropriate to be used as the measuring indicators. Visually, the structural and measurement model in this recent research is presented in Figure 1, while the value of the Goodness of Fit Model is presented in Table 3.

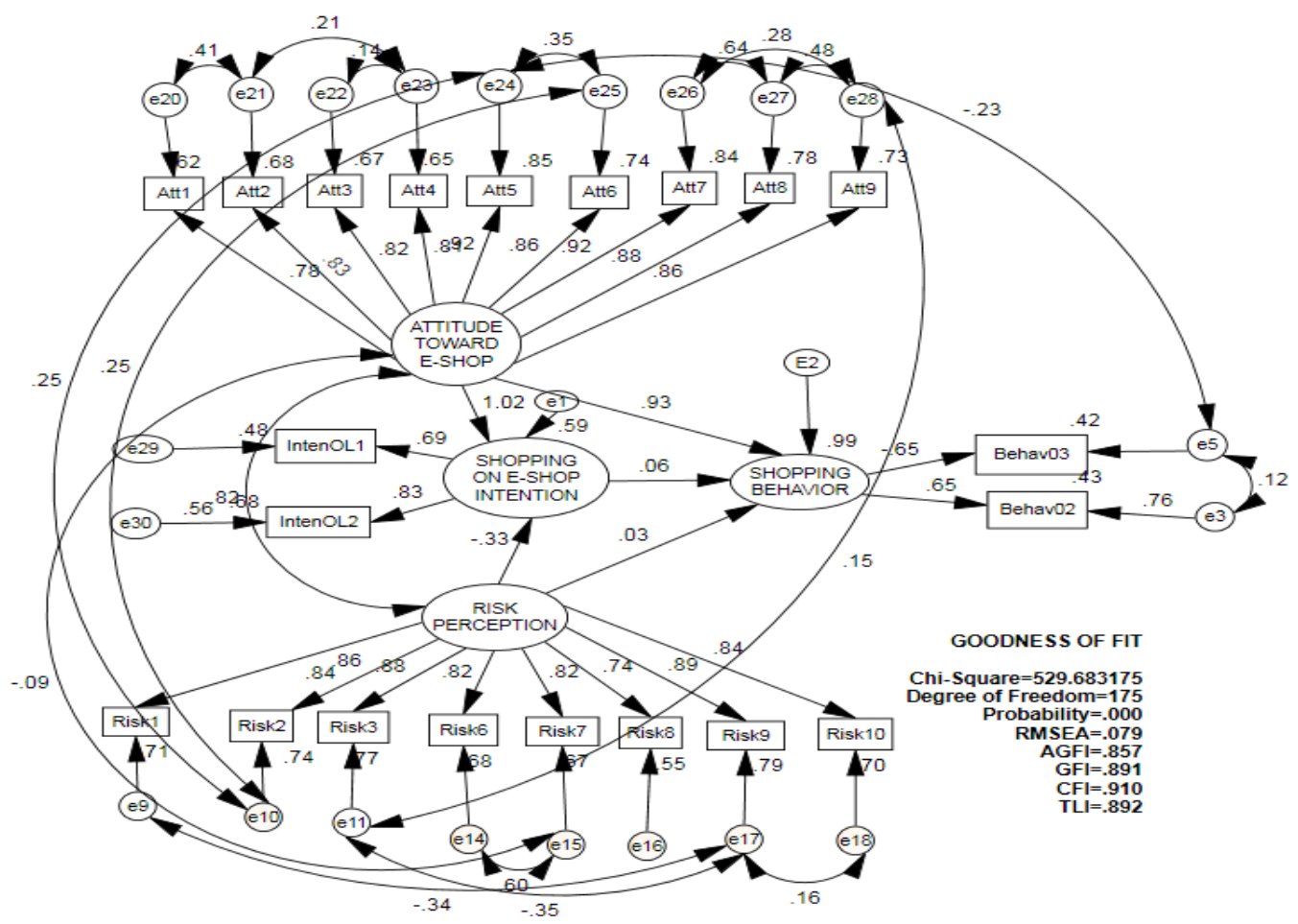

Figure 1 Full (Structural dan Measurement) Model with Standardized Coefficient

Figure 1 shows the construction of a latent variable with a valid indicator, indicated by a standardized coefficient value greater than 0.6. It also shows the standardized coefficients of the hypothesized latent variables. The amount of the standardized coefficient (Estimate), the statistical value (CR) and p-value (probability value) for the latent variable relation paths tested in this research model are contained in Table 4. In the table, it is shown that not all coefficients of latent latitude on the model are statistically significant. A path with $C R$ value greater than 1.96 , and a p-value smaller than 0.05 indicates significant, so the null hypothesis $(\mathrm{H0})$ is rejected. The magnitude of the path coefficient, the critical value (CR), p-value and the acceptance decision of the hypothesis of all the paths model constructed are presented in Table 4.

Table 4 Summary of hyphoteses test

\begin{tabular}{|c|c|c|c|c|c|c|c|}
\hline & Path & & Estimate & S.E. & C.R. & $\mathrm{P}$ & Decision \\
\hline $\begin{array}{l}\text { Shopping On } \\
\text { E-Shop Intention }\end{array}$ & $\leftarrow$ & $\begin{array}{l}\text { Attitude Toward } \\
\text { E-Shop }\end{array}$ & 0.557 & 0.079 & 7.056 & 0.000 & Ho rejected \\
\hline $\begin{array}{l}\text { Shopping On } \\
\text { E-Shop Intention }\end{array}$ & $\leftarrow$ & Risk Perception & -0.185 & 0.066 & -2.817 & 0.005 & Ho rejected \\
\hline $\begin{array}{l}\text { Shopping } \\
\text { Behavior }\end{array}$ & $\leftarrow$ & Risk Perception & 0.023 & 0.067 & 0.338 & 0.735 & $\begin{array}{l}\mathrm{H}_{0} \text { not } \\
\text { rejected }\end{array}$ \\
\hline $\begin{array}{l}\text { Shopping } \\
\text { Behavior }\end{array}$ & $\leftarrow$ & $\begin{array}{l}\text { Shopping On } \\
\text { E-Shop Intention }\end{array}$ & 0.068 & 0.116 & 0.582 & 0.561 & $\begin{array}{l}\mathrm{H}_{0} \text { not } \\
\text { rejected }\end{array}$ \\
\hline $\begin{array}{l}\text { Shopping } \\
\text { Behavior }\end{array}$ & $\leftarrow$ & $\begin{array}{l}\text { Attitude Toward } \\
\text { E-Shop }\end{array}$ & 0.609 & 0.103 & 5.921 & 0.000 & $\mathrm{H}_{0}$ rejected \\
\hline
\end{tabular}

Source: Amos Printout 


\section{The Roles of Attitude towards Online Shopping Intention}

In the Theory of Planned behavior or the Theory of Reasoned Action, attitude influences the formation of the intention to do a certain action. The emergence of online shopping intention in the adolescences was assumed to be influenced by their attitude. Empirically, this theory has been much applied to explain the phenomenon of online shopping and the results have confirmed the roles of attitudes in behavior intention. At the case of online shopping, the consistency of the relation between the two variables may be shown. The attitudes towards online shopping system played the roles of influencing the emergence or encouraging the shopping intention via online media. The results of the present research in terms of the roles of attitude in raising the online intention among adolescents also were also similar. The path coefficient of the relationship between attitude and significant intention became the standard to confirm the significance of the relationship between the two variables. Similar researches showing the relationship in the significant roles between the attitudes towards various online shopping aspects and the shopping intention may be found in various scientific plublications, for examles those made by Park (2009), Delafrooz et al. (2010), Thompson (2010), Hsu and Bayarsaikhan (2012a), Shoki et al. (2014), Zendehdel et al. (2015), Khan and Chavan (2015), Haryo and Budhi (2015), and Juho (2015), although as a whole their research results are not the same as the results of this present research. But there is a similarity in one variable tested, namely attitude, and the result indicated that attitudes affected the online shopping intention.

\section{The Effects of Risk Perception on Shopping Intention}

Consumers'risk perception of the online shopping was indicated from the effects of their intention to choose online shopping. Due to the characters of the online shopping system, a lot of consumer making online shopping consider or calculate some risks they would face such as among others the quality of the goods that is not as good as expected, the possibility that the goods would not come on time, even the misuse of personal data. The results of the data analysis indicated that the risk perception gave the effect of the consumers' intention to do online shopping. The significant negative value of the path coefficient showed that the risk perception variable gave effect in the consumers' intention to do online shopping. Meanwhile, the negative sign showed that if the risk was higher, then the intention to do online shopping would be lower, and vice versa. The result of this present research is in line with that of other researchers trying to test the risk or risk perception of various forms of online shopping in shopping intention. Some researchers showed results similar to those of this present research. Forsythe et al. (2004) described a model becoming the antecedent of the intention in online shopping. In the model, the risk perception became an antecedent variable influencing the online shopping intention, besides that of the benefits. Lin (2008) tested two factors, namely the subjective norms and risk perception as the internal variable influencing the online shopping intention and behavior of. The result of the testing showed that the risk perception contributed to the online shopping behavior. Moreover, Hsu and Bayarsaikhan (2012a) also tested the risk perception variable to the online shopping context. The result showed that the risk perception gave negative effects on the online shopping intention. Other researchers showed the same results, among others Shoki et al. (2014), Arshad et al. (2015b), Khan and Chavan (2015), dan Haryo and Budhi (2015).

\section{The effects of Intention on Shopping Behavior}

The basic theory used to explain the online shopping phenomenon in this present research is The Theory of Planned Behavior. In the theory, it is described that the closest variable as the explanatory variable is the intention. This theory has been applied in the many contexts of online shopping such as George (2004), Lim and Dubinsky (2005), and also Lee and Ngoc (2010). If this theoretical model is adopted, the explanatory variable closest to the online shopping behavior is the intention. Many researchers showed that online shopping intention gave effects on online shopping behavior. Jin et al. (2016) showed that intention gave significant effects on online shopping. But in this present research, it is not the case that intention is not the explanatory variable closest and the most significant to the online shopping attitude. This indicates that the adolescents, serving as the respondents in this present 
research, did not base their online shopping on their rational intention. Their online shopping was irrational impulsive based on hedonic attitude. This is also mentioned in the research results made by Gültekin and Özer (2016), but the research result made by Chen (2008) showed that online shopping tended to be impulsive in purchasing certain types of goods.

\section{Conclusions}

Some conclusions are made from the research results. The attitude towards online shopping and risk perception in online shopping has influenced or contribute to the emergence of online shopping intention. Positive attitude towards the characteristics of an online shopping system has given effects on the emergence of high intention of consumers or candidates of consumers to do online shopping. The risk perception that would happen to consumers has also influenced online shopping intention. The higher risks or losses consumers face, the lower the consumers' intention to do online shopping will be. The contribution of the effects of intention to online shopping is not significant. Theoretically, especially the Theory of Planned Behavior, the intention would contribute to the emergence of behavior. This applies to the normal condition. It means that the actors thought rationally. In the case of online shopping, the relationship between intention and behavior would be significant under the rational condition. Consumers doing online shopping seemed irrational or especially, especially, in this case, the adolescents tended to be irrational. They did shopping without any planning, but he did it in a hedonic and impulsive, or irrational way. Therefore, intention does not base the attitude towards online shopping.

\section{References}

Ahmad, N., Vanja, G., \& Wamadeva, B. (2014). Consumer Attitudes toward Online Shopping. International Journal of Social Ecology and Sustainable Development, 5(3), 13-24. doi: 10.4018/ijsesd.2014070102

Akin, Z., \& Seçilmişb, İ. E. (2015). Risk Behavior, Risk Perception and Online Shopping: An Experimental Approach. doi: 10.13140/RG.2.1.4956.9761

Al, N. (2014). Effects of Consumersâ Trust and Attitude toward Online Shopping. American Journal of Economics and Business Administration, 6(2), 58-71. doi: 10.3844/ajebasp.2014.58.71

APJII. (2014). Profil Pengguna Internet Indonesia. In P. UI (Ed.). Jakarta: Asosiasi Penyelenggara Jasa Internet Indonesia

Ariff, M. S. M., Sylvester, M., Zakuan, N., Ismail, K., \& Ali, K. M. (2014). Consumer Perceived Risk, Attitude and Online Shopping Behaviour; Empirical Evidence from Malaysia. IOP Conference Series: Materials Science and Engineering, 58, 012007. doi: 10.1088/1757-899x/58/1/012007

Arshad, A., Zafar, M., Fatima, I., \& Khan, S. K. (2015). The Impact of Perceived Risk on Online Buying Behavior International Journal of New Technology and Research (IJNTR), 1(8), 5.

Bhatt1, A. (2014). Consumer Attitude towards Online Shopping in Selected Regions of Gujarat. Journal of Marketing Management, 2(2), 29-56.

Chandra, A. K., \& Sinha, D. K. (2013). Factors Affecting The Online Shopping Behaviour: A Study With Reference To Bhilai Durg. International Journal of Advanced Research in Management and Social Sciences, 2(5), 17.

Cheng, F.-F., Liu, T.-Y., \& Wu, C.-S. (2013). Perceived Risks And Risk Reduction Strategies In Online Group-Buying. Paper presented at the International Conference on Technology Innovation and Industrial Management, Phuket Thailand.

Dijst, M., Farag, S., \& Schwanen, T. (2005). Attitude theory applied to in-store and online shopping.

Galina, S., Oleksiy, O., \& Karina, B. (2016). Exploring the intention-behavior link in student entrepreneurship: Moderating effects of individual and environmental characteristics. European Management Journal, 34(4), 13. doi: 10.1016/j.emj.2015.12.007

Haryo, P., \& Budhi, H. (2015). Factors Affecting Purchase Intention of Online Shopping in Zalora Indonesia. British Journal of Economics, Management \& Trade, 9(1), 1-12. doi: 10.9734/bjemt/2015/18704 
Hong, L. M., Zulkiffli, W. F. W., \& Hamsani, N. H. (2016). The Impact Of Perceived Risks Towards Customer Attitude In Online Shopping. International Journal of Accounting, Finance and Business, 1(2), 8 .

Hsu, S.-H., \& Bayarsaikhan, B.-E. (2012). Factors Influencing on Online Shopping Attitude and Intention of Mongolian Consumers. The Journal of International Management Studies, 7(2), 18.

Jain, D., Goswami, S., \& Bhutani, S. (2014). Consumer Behavior towards Online Shopping: An Empirical Study from Delhi. IOSR Journal of Business and Management (IOSR-JBM), 16(9), 7.

Joseph F. Hair, William C. Black, Barry J.Babin, \& Anderson, R. E. (2009). Multivariate Data Analysis (Seventh Edition ed.).

Jusoh, Z. M., \& Ling, G. H. (2012). Factors Influencing Consumers' Attitude Towards E-Commerce Purchases Through Online Shopping. International Journal of Humanities and Social Science, 2(4).

Kautonen, T., Van Gelderen, M., \& Fink, M. (2015). Robustness of the Theory of Planned Behavior in Predicting Entrepreneurial Intentions and Actions. Entrepreneurship Theory and Practice, 39(3), 655-674. doi: 10.1111/etap.12056

Li, N., \& Zhang, P. (2002). Consumer Online Shopping Attitudes And Behavior: An Assessment Of Research. Paper presented at the Eighth Americas Conference on Information Systems.

Mariani, M. G. (2012). Risk perception in online shopping.

Masoud, E. Y. (2013). The Effect of Perceived Risk on Online Shopping in Jordan. European Journal of Business and Management, 5(6), 11.

Shafeeque, A. P. M., \& Thomachan, K. T. (2017). Risk Perception In E-Commerce: A Holistic Review Of Emerging Online Shopping In India. International Journal of Research Grantaalayah, 5(6), 8. doi: 10.5281/zenodo.820533

Shergill, G. S., \& Chen, Z. (2005). Web-Based Shopping: Consumers' Attitudes Towards Online Shopping In New Zealand. Journal of Electronic Commerce Research, 6(2), 15.

Shirokova, G., Osiyevskyy, O., \& Bogatyreva, K. (2016). Exploring the intention-behavior link in student entrepreneurship: Moderating effects of individual and environmental characteristics. European Management Journal, 34(4), 386-399. doi: 10.1016/j.emj.2015.12.007

Smith, J. R., Manstead, A. S. R., Terry, D. J., Louis, W. R., Kotterman, D., \& Wolfs, J. (2007). Interaction Effects in the Theory of Planned Behavior: The Interplay of Self-Identity and Past Behavior Journal of Applied Social Psychology, 37(11), 2726-2750.

Sreya, R., \& Raveendran, P. T. (2016). Dimensions Of Perceived Risk In Online Shopping - A Factor Analysis Approach Journal of Management Research and Analysis, 8(1), 5.

Teo, T. S. H. (2010). Attitudes toward online shopping and the Internet. Behaviour \& Information Technology, 21(4), 259-271. doi: 10.1080/0144929021000018342 